\section{God introduksjon til forbrukergenetikken}

Lone Frank

Mit smukke genom

Historier fra genetikkens overdrev.

307 s. København: Gyldendal, 2010.

Pris DKK 299

ISBN 978-87-02-08115-2

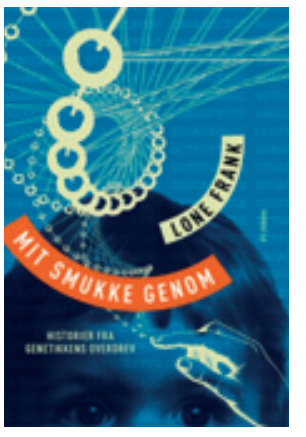

Lone Frank har doktorgraden i nevrobiologi og er vitenskapsjournalist i Weekendavisen. Hun har skrevet flere naturvitenskapelige bøker. Mit smukke genom er ingen lærebok i genetikk, men en interessant introduksjon til en del genetiske dilemmaer. Genetikk er ikke lenger bare forbeholdt forskere og fagfolk, men er for fullt på vei inn i hverdagen for folk flest.

Mange steder i USA - bl.a. på supermarkeder - får man kjøpt utstyr for innsending av spyttprøve eller avskrap fra munnslimhinnen til kartlegging av ens eget genom. Privat gentesting er etter hvert blitt stor forretning. Men har vi godt av å få kunnskap om vår genetiske profil? Flere er usikre på det, og mange tar til orde for at «vanlige mennesker» ikke bør la seg genteste uten samtidig profesjonell rådgivning. «Hvem som er ved sine fulle fem vil ønske den viden?» I Tyskland og California har man bestemt at genetiske tester bare kan bestilles av lege.

Forfatteren, som kommer fra en familie med opphopning av både somatisk og psykisk sykdom, ønsket å få kunnskap om sin egen arvemasse og «hva det helt nøjaktig er for genetiske varianter og mutationer, som er blevet lagt i min biologiske matpakke, og hva de betyder for hvem jeg er.» Hun meldte seg som frivillig testperson $i$ et stort prosjekt, og beskriver de ulike fasene hun gjennomlevde mens hun ventet på resultatene. Hun ble svært lettet over å få konstatert at hun selv ikke hadde kjent genetisk disposisjon for bryst- eller ovarialkreft. Men på grunn av familieopphopningen av brystkreft ble hun ikke «frikjent». «Vi kan ikke vide, hva det var, som gjorde seg gjeldende hos din mor og mormor. Det kan sagtens ha været feil i gener, vi slet ikke kender til endnu, og som er gået $i$ arv til dig.»

Et dilemma er at man også risikerer å få ulike svar på den samme gentesten. Ikke fordi ens genmateriale forandrer seg, men fordi testrepertoaret og tolkningen av testene varierer. Det kan gi ulik risikoprofil hos en og samme person, avhengig av hvor man sender inn testen.

Mennesket deler $98 \%$ av sin arvemasse med sjimpanser, $60 \%$ med mus og $20 \%$ med rundormer. Det er derfor ikke bare sekvensen av genene som er viktig, men også hvor aktive de er. Forfatteren gir en god introduksjon til epigenetikken: hvordan miljøfaktorer (herunder mat), erfaringer, tanker og følelser kan påvirke aktiviteten og funksjonen til våre gener.

Forfatteren har snakket med flere forskere som arbeider med å forklare hvordan forskjellene i sykelighet, sykdomsforløp og dødelighet i ulike sosioøkonomiske klasser kanskje kan forklares ut fra epigenetiske forhold. Som en forsker uttrykker det: «Og forskellen kan jo dårlig skyldes, at de fattige har nogle andre gener enn de rige. Det er så oplagt, at her foregår noget epigenetisk, men ingen har set på det.» Virkelig interessant og vanskelig blir det når man i tillegg postulerer at forskjellige mennesker har ulike genvarianter, som gjør det ulikt vanskelig å indusere bestemte epigenetiske forandringer.

Noen forskere hevder at gener kan disponere for en bestemt personlighetsmessig «følsomhet». Faktorer i livsstilen eller miljøet kan så utløse denne følsomheten, for eksempel kan «depresjonsgener», hvis slike finnes, virke ved at disponerte personer lettere får problemer i medmenneskelige relasjoner og derved blir deprimerte. Noen antyder til og med at det å bli utsatt for vold kan være delvis genetisk bestemt, ved at genene bidrar til å forme en atferd, som øker risikoen for at man oppsøker risikomiljøer.

Et aktuelt anvendelsesområde for gentesting er kartlegging av gener som styrer enzymatisk omsetning av medikamenter. Forfatteren refererer en rapport som postulerer at man i løpet av ti år ikke vil kunne selge et medikament uten samtidig å selge en diagnostisk test som dokumenterer at pasienten skal ha nettopp det medikamentet. Det kan få store økonomiske konsekvenser, fordi det kan bli færre brukere per medikament.

En «nyvinning» er dating ved hjelp av gentesting. En rekke kommersielle firmaer tilbyr nå rådgivning om partnervalg, basert på likheter og ulikheter i gensekvenser. Det vitenskapelige grunnlaget er foreløpig magert, «men sex sælger, og det gør videnskap også.»

Misbruk av genteknologi blir også omtalt - bl.a. hvordan man kan skaffe seg en persons DNA fra avklippede negler, tannbørster, drikkekrus eller baksiden av frimerker man har slikket på. Flere politikere og forretningsfolk i USA skal ha medarbeidere som samler inn drikkebegre og annet materiale etter sammenkomster, for å hindre misbruk av gentesting.

Forfatteren omtaler flere sosiale helsenettverk, som Microsoft Health Vault og Google Health, hvor pasienter kan etablere sin egen «helsekonto» og elektroniske journal. Pasienter med ulike kroniske sykdommer slår seg sammen i sosiale nettverk og etablerer til og med egne forskningsprosjekter. I USA er spørsmålet for lengst stilt om hvordan man skal forholde seg til legenes manglende kunnskap om genetikk. Hvem skal ta ansvaret når personer tester seg hos private firmaer, og legene ikke kan tolke svarene?

Forfatteren tegner et dystert bilde av fremtidens leger: «En hvidkitlet mellemmand, som har den nødvendige autorisation til at skaffe oss de ydelser, sundhedssystemerne udbyder, men som i mange tilfælde ikke ved mer end vi selv gør.»

Hun har snakket med en rekke forskere $i$ feltet, og boken er delvis skrevet i intervjuform. Det gjør at fremstillingen enkelte steder er litt løs i strukturen. Men forfatteren er meget kunnskapsrik, skriver stedvis humoristisk, og får frem poengene på en forståelig måte for de av oss som ikke er spesialister i faget. Boken illustrerer noen av dilemmaene ved informert samtykke, og hvor vanskelig det er. Det er mange referanser av ny dato.

Genteknologien - inkludert epigenetikken - står foran en rivende utvikling. Forfatteren gir leseren en god forståelse av genetikkens mange muligheter, men også dens store begrensninger. En av konklusjonene er at per i dag har genetisk testing en meget begrenset klinisk nytteverdi.

Leger som skal gi råd i gen-etiske spørsmål, vil finne nyttig bakgrunnsinformasjon i denne boken.

\section{Jan Harald Dobloug}

Gjensidige Forsikring 